\title{
Pembuatan Geo Produk 'Makrame Oluhuta' Untuk Meningkatkan Perekonomian Masyarakat Di Desa Oluhuta
}

\author{
Nurul Istiqamah Kadekoh ${ }^{1}$, Putri Warsono ${ }^{2}$, Ardiman $^{3}$, \\ Yowan Moha $^{3}$, Intan Noviantari Manyoe ${ }^{4 *}$ \\ ${ }^{1}$ Pendidikan Bahasa Inggris, Universitas Negeri Gorontalo \\ ${ }^{2}$ Administrasi Publik, Universitas Negeri Gorontalo \\ ${ }^{3}$ Manajemen Sumberdaya Perairan, Universitas Negeri Gorontalo \\ ${ }^{4}$ Teknik Geologi, Universitas Negeri Gorontalo \\ *Email: intan.manyoe@ung.ac.id
}

Received: 13 August 2021; Revised: 02 October 2021; Accepted: 14 December 2021

DOI: http://dx.doi.org/10.37905/aksara.8.1.155-164.2022

\begin{abstract}
Abstrak
Desa Oluhuta memiliki kekayaan geo diversity dan bio diversity yang melimpah, namun perlu untuk diptomalisasikan, misalnya dengan cara memproduksi sebuah geo produk. Dari hasil survei tim PHP2D UKM Literasi, di Desa Oluhuta terdapat banyak sekali fosil kerang di sekitaran pantai Oluhuta yang bisa dikreasikan menjadi sebuah geo produk. Tujuan penulisan artikel ini yakni untuk menjelaskan serta menguraikan proses pembuatan geo produk khas desa Oluhuta yang diberi nama 'Makrame Oluhuta' serta tahapan yang dilakukan dalam memperkenalkan geo produk tersebut pada masyarakat setempat. Hasil yang diperoleh menunjukkan bahwa Makrame Oluhuta yang diproduksi masyarakat setempat mempunyai nilai jual dan daya tarik yang tinggi, dan mampu meningkatkan perekonomian masyarakat setempat dari hasil penjualannya, serta menjadi salah satu instrumen pendukung bagi Desa Oluhuta untuk menjadi desa edugeowisata.
\end{abstract}

Kata Kunci: Geo Produk, Makrame, Edu-geowisata.

\section{PENDAHULUAN}

Sektor pariwisata memiliki peran penting bagi kesejahteraan suatu negara, karena dapat menjadi pendorong bagi pertumbuhan ekonomi nasional dengan mengurangi jumlah pengagguran, sebab sektor pariwisata mampu membuka berbagai lapangan pekerjaan dan sumber penghasilan bagi masyarakat (Utami, 2016). Terlebih lagi, saat ini Indonesia sedang gencar mengembangkan konsep wisata geopark yang fokus pada tiga aspek utama yakni konservasi kawasan wisata, edukasi dan penelitian, dan peningkatan kesejahteraan ekonomi masyarakat (Patzak \& Eder, 1998). Konsep ini sejalan dengan salah satu konsep wisata baru yang disebut dengan edu-geowisata, yakni konsep wisata yang menitik beratkan pada nilai edukasi potensi wisata sehingga dapat menciptakan kesadaran bagi para wisatawan untuk ikut melestarikannya, dan juga membuka lapangan pekerjaan baru bagi penduduk yang tinggal di sekitar area wisata sehingga berdampak pada peningkatan ekonomi masyarakat (Manyoe, et.al 2020).

Terdapat banyak daerah di Provinsi Gorontalo yang menyimpan kekayaan geodiversity dan biodiversity, salah satunya yaitu Desa Oluhuta. Potensi geo diversity yang terdapat di desa Oluhuta antara lain situs manusia Oluhuta, situs lautan terangkat, dan columnar joint atau kekar kolom, sedangkan potensi bio diversity Desa Oluhuta Petrosia lignosa, terumbu karang, dan juga ribuan ikan karang. Maka dari itu, desa Oluhuta tergolong desa yang potensial untuk dikembangkan menjadi suatu 
destinasi wisata menggunakan konsep edu-geowisata, sehingga dapat berdampak pada peningkatan pereknomian masyarakat setempat.

Salah satu cara yang bisa diimplementasikan guna meningkatkan perekonomian masyarakat lewat sektor pariwisata yakni melalui pembuatan suatu produk yang khas, unik, dan memiliki nilai jual (Setyadi, 2012). Di Desa Oluhuta sendiri, terdapat banyak fosil kerang di sekitar lokasi pantai Oluhuta yang bisa diolah menjadi suatu geo produk berupa kerajinan tangan yang memiliki nilai estetika, yang disebut dengan Makrame Oluhuta.

Makrame Oluhuta merupakan kerajinan menggunakan material benang katun yang dibuat menggunakan teknik simpul dengan tambahan hiasan fosil kerang yang sudah diwarnai. Geo produk Makrame Oluhuta ini nantinya akan menjadi cinderamata bagi para wisatawan yang berkunjung di Desa Oluhuta. Oleh karena itu, dengan keunikan dan keindahan geo produk Makrame Oluhuta ini, menjadikannya suatu produk kerajinan yang memiliki daya tarik dan nilai jual yang tinggi, sehingga dapat menarik minat wisatawan untuk membelinya, dan alhasil pendapatan dari hasil penjualan ini dapat meningkatkan perekonomian masyarakat.

\section{METODE PENELITIAN}

Kegiatan Program Holistik Pembinaan dan Pemberdayaan Desa (PHP2D) dilaksanakan pada bulan Juli sampai Desember 2021. Salah satu fokus utama kegiatan PHP2D UKM Literasi yakni pembuatan geo produk Makrame Oluhuta di Desa Oluhuta, Kecamatan Kabila Bone, Kabupaten Bone Bolango.

Metode pelaksanaan pembuatan geo produk Makrame Oluhuta sebagian besar dilaksanakan di lapangan, karena berdasarkan laporan Gugus Tugas Covid-19 Provinsi Gorontalo, Desa Oluhuta tergolong dalam zona hijau sehingga pelaksanaan program kegiatan di lapangan secara langsung bisa dilaksanakan, selama tetap mematuhi protokol kesehatan. Ada empat metode yang digunakan dalam pelaksanaan program pembuatan geo produk Makrame Oluhuta, diantaranya, Tim PHP2D UKM Literasi melakukan survei lokasi di situs-situs edu-geowisata dan mengidentifikasi permasalahan dan potensi yang bisa dioptimalisasikan, serta membicarakan seluruh program yang akan dibuat mulai dari konsep pelaksanaan program, administrasi, sasaran, serta tempat dan lokasi pelaksanaan program.

Sosialisasi dilakukan dengan tujuan untuk mengenalkan gambaran dari geo produk Makrame Oluhuta kepada mitra. Tim PHP2D UKM Literasi juga menjelaskan dan memaparkan terkait tujuan pembuatan geo produk tersebut, manfaatnya dalam peningkatan ekonomi masyarakat, dan target pelaksanaan pelatihan pembuatan geo produk Makrame Oluhuta. Selain itu, tim PHP2D UKM Literasi juga mengadakan sosialisasi mengenai konsep edu-geowisata secara keseluruhan. Dalam proses sosialisasi, mitra berperan dalam menyediakan tempat sosialisasi dan juga mengumpulkan dan mengajak masyarakat setempat untuk mengikuti sosialisasi yang diadakan.

Alat dan bahan yang digunakan dalam pembuatan geo produk Makrame Oluhuta tergolong mudah didapatkan dan harganya juga sangat ekonomis. Apalagi salah satu bahan yang digunakan merupakan fosil kerang yang berada di sekitar pantai Oluhuta dan situs lautan terangkat yang tidak termanfaatkan. Sehingga, diperkirakan harga jual dari Makrame Oluhuta terjangkau bagi seluruh kalangan masyarakat. 
Pelatihan pembuatan geo produk Makrame Oluhuta bertujuan untuk memberikan pengetahuan dan pemahaman mitra terkait cara pembuatan Makrame Oluhuta, terutama simpul-simpul yang digunakan pada pembuatan Makrame Oluhuta tersebut. Dikarenakan ke depannya para mitra lah yang akan aktif memproduksi dan memasarkan geo produk Makrame Oluhuta.

Tim PHP2D UKM Literasi mendampingi mitra yang dalam hal ini adalah Gerakan Pemuda Pembaharu atau karang taruna Desa Oluhuta dalam mempromosikan geo produk Makrame Oluhuta di berbagai platform media sosial yang sudah dibuat, seperti Instagram, Facebook, TikTok, dan YouTube. Hal ini bertujuan untuk menjangkau lebih banyak calon pembeli.

Dampak yang diharapkan dari pembuatan geo produk Makrame Oluhuta ini adalah meningkatnya perekonomian masyarakat Desa Oluhuta berkat hasil penjualan dari geo produk pada para wisatawan. Geo produk ini juga diharapkan mampu menarik minat wisatawan untuk berkunjung ke Desa Oluhuta. Selain itu, Makrame Oluhuta juga dapat menjadi product branding yang menjadi ciri khas Desa Oluhuta yang membedakannya dengan desa yang lain, serta menjadi media untuk melatih kreativitas masyarakat dalam menghasilkan suatu produk yang berkualitas dan memberikan ilmu atau pengetahuan baru melalui pelatihan pembuatan geo produk Makrame Oluhuta.

\section{HASIL DAN PEMBAHASAN}

Program pembuatan geo produk Makrame Oluhuta telah dilaksanakan di Dusun Pantai, Desa Oluhuta, Kecamatan Kabila Bone. Program ini merupakan sub program dari pengoptimalisasian situs-situs edu-geowisata di Desa Oluhuta. Geo produk Makrame Oluhuta ini akan menjadi cenderamata khas dari Desa Oluhuta yang selain menjadi daya tarik wisatawan untuk berkunjung juga dapat meningkatkan pereknomian masyarakat lewat hasil penjualannya. Adapun tahapan-tahapab yang dilakukan tim PHP2D UKM Literasi dalam melakukan program pembuatan geo produk Makrame Oluhuta antara lain:

1) Tahap Perencanaan

Pada tahap pertama ini, tim PHP2D UKM Literasi melakukan komunikasi dan koordinasi dengan Kepala Desa dan juga ketua Gerakan Pemuda Pembaharu (GPP) atau karang taruna Desa Oluhuta mengenai kesediaan mereka sebagai mitra pada program utama tim yakni menjadikan Desa Oluhuta sebagai desa edu-geowisata, dan menjabarkan sub-sub program lainnya salah satunya pembuatan geo produk. Berdasarkan hasil wawancara terbatas bersama bersama Kepala Desa Oluhuta bapak Ronal Sahrain S.H., dan juga hasil survei lokasi situs-situs edu-geowisata Desa Oluhuta, khususnya lokasi situs lautan terangkat, tim PHP2D UKM Literasi menemukan banyak fosil kerang di sekitaran pantai Oluhuta dan juga situs lautan terangkat yang sama sekali tidak dimanfaatkan padahal memiliki nilai estetika yang tinggi dengan aneka bentuk yang menarik dan unik, yang bisa dikreasikan menjadi suatu geo produk. Selain itu, juga diketahui bahwa pendapatan penduduk pada tahun 2017 sejak Oluhuta dijadikan desa wisata sempat meningkat sebesar 250-300 ribu/hari, namun seiring berjalannya waktu ditambah dengan adanya pandemi Covid-19 membuat pendapatan masyarakat setempat mengalami penurunan. Apalagi, sebagaian besar masyarakat Desa Oluhuta hanya berprofesi sebagai 
nelayan dan petani, sehingga tentunya memerlukan pendapatan tambahan dari sumber pencaharian yang lain pula.

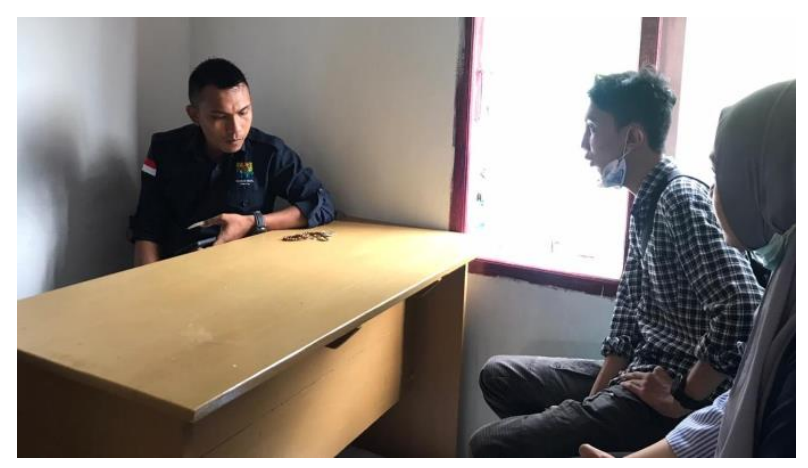

Gambar 1. Diskusi terbatas bersama Kepala Desa Oluhuta.

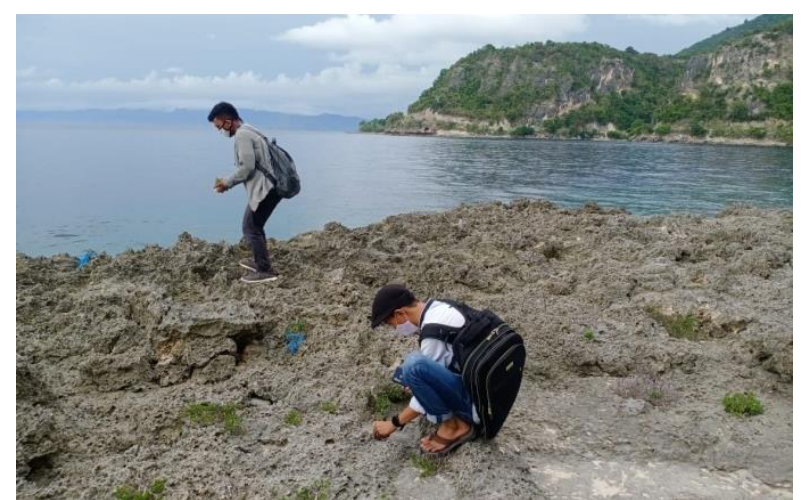

Gambar 2. Survei lokasi oleh tim PHP2D UKM Literasi di Situs Lautan Terangkat.

Selanjutnya, berdasarkan arahan kepala Desa Oluhuta, tim PHP2D UKM Literasi bersama ketua Gerakan Pemuda Pembaharu Desa Oluhuta, Usman Sami mulai bekerja sama menyusun perencanaan pelaksanaan program pembuatan geo produk termasuk agenda pelatihan pembuatannya pada masyarakat setempat.

2) Tahap Sosialisasi

Tim PHP2D UKM Literasi melakukan sosialisasi program dalam dua tahap, tahap pertama pada masyarakat dan Gerakan Pemuda Pembaharu (GPP) Desa Oluhuta dan yang kedua yakni pada aparat desa Oluhuta.

\section{a. Sosialisasi Program Tahap 1}

Tim PHP2D UKM Literasi telah melakukan sosialisasi terkait programprogram yang akan dibuat di Desa Oluhuta, untuk menjadikannya desa edugeowisata, termasuk sosialisasi program pembuatan geo produk yang bernama Makrame Oluhuta. Kegiatan sosialisasi tahap pertama ini dilaksanakan di kantor Desa Oluhuta dan dihadiri oleh kurang lebih 20 orang yang merupakan gabungan dari anggota Gerakan Pemuda Pembaharu (GPP) Desa Oluhuta dan juga masyarakat setempat.

Sosialisasi diawali dengan pemaparan program utama yang akan diimplementasikan di Desa Oluhuta untuk memajukan sektor pariwisata di desa tersebut, sehingga Desa Oluhuta dapat menjadi desa edu-geowisata. 
Selanjutnya, tim PHP2D UKM Literasi yang berperan dalam sosilasasi menjabarkan dan menyebutkan sub-sub program lainnya, termasuk dengan pembuatan geo produk, meliputi rencana pelatihan pembuatannya pada masyarakat. Kemudian untuk mengetahui respons dan tanggapan dari masyarakat dan juga GPP, tim PHP2D UKM Literasi melakukan diskusi bersama dan masyarakat ataupun GPP diberi kesempatan untuk menanggapi sosialisasi yang telah disampaikan. Sosialisasi ini mendapatkan tanggapan yang positif dari masyarakat dan juga GPP yang merupakan mitra utama tim PHP2D UKM Literasi. Hal ini terlihat dari antusias mereka dalam memberi pertanyaan dan juga mengemukakan saran dan masukkan untuk program-program yang akan dilaksanakan, termasuk program pembuatan geo produk Makrame Oluhuta.

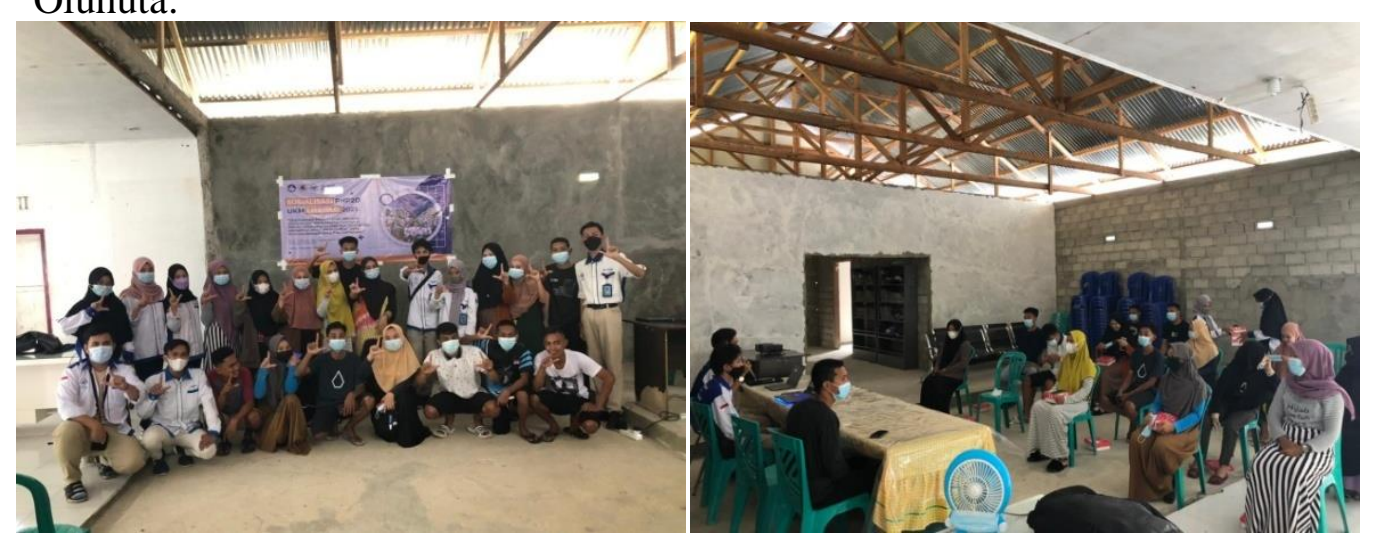

Gambar 3. Sosialisai Tahap 1 terkait Program PHP2D UKM Literasi, termasuk

Pembuatan Geo Produk Makrame Oluhuta bersama masyarakat dan Gerakan Pemuda Pembaharu Desa Oluhuta.

b. Sosialisasi Tahap 2

Tidak jauh berbeda dari sosialisasi tahap pertama, sosialisasi yang kedua juga dilaksanakan di kantor desa Oluhuta, namun kali ini bersama aparat-aparat desa. Tahapan atau jalannya sosialisasi juga dimulai dengan memaparkan program utama lalu dilanjutkan pada sub-sub program termasuk di dalamnya pembuatan geo produk Makrame Oluhuta. Kemudian dilanjutkan dengan diskusi sebagai bentuk timbal balik dari aparat-aparat desa Oluhuta terkait program tim PHP2D UKM Literasi yang akan dilaksanakan. Respons dari aparat desa terkait program yang ditawarkan tim PHP2D UKM Literasi sangat positif, bahkan para aparat desa, salah satunya sekretaris desa mengungkapkan bahwa program ini akan memberikan dampak yang sangat baik apabila dilaksanakan dengan gotong royong dan kerja sama dari seluruh pihak. Beliau juga menyatakan bahwa seluruh aparat desa mendukung penuh seluruh program yang akan dijalankan oleh tim PHP2D UKM Literasi di Desa Oluhuta. 

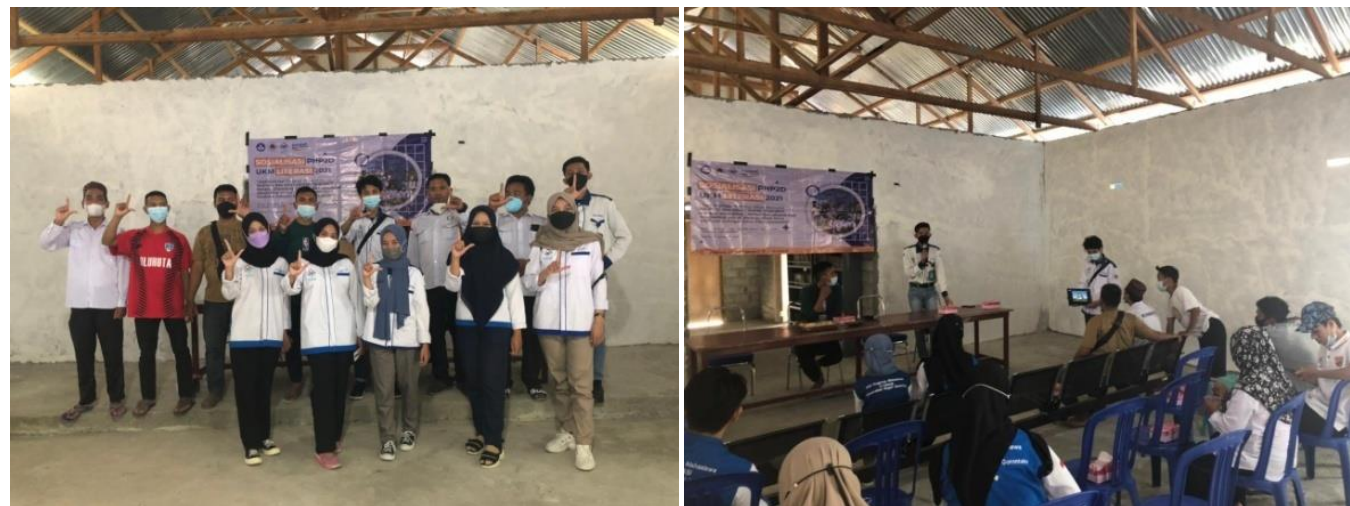

Gambar 4. Sosialisai Tahap 2 terkait Program PHP2D UKM Literasi, termasuk Pembuatan Geo Produk Makrame Oluhuta bersama aparat desa Oluhuta.

\section{3) Tahap Pengadaan Alat dan Bahan}

Dalam pembuatan geo produk Makrame Oluhuta, bahan-bahan utama yang diperlukan dipesan melalui platform belanja online, dengan pertimbangan stok barang yang diinginkan lebih bervariasi dan harganya pun lebih murah. Berikut merupakan alat dan bahan yang digunakan dalam pembuatan Makrame Oluhuta:

a. Alat

1. Gunting: digunakan untuk memotong benang sesuai ukuran yang diinginkan dan dibutuhkan, juga untuk merapikan benang yang sudah dibentuk.

2. Sisir rapat: digunakan sebagai alat untuk merapikan benang-benang yang mulai kusut dan berlilitan.

3. Pistol lem tembak: berfungsi sebagai alat untuk melelehkan lem tembak untuk merekatkan kerang pada benang katun yang sudah dibentuk.

4. Kuas lukis: digunakan untuk mewarnai atau melukis fosil kerang agar lebih cantik dan menarik.

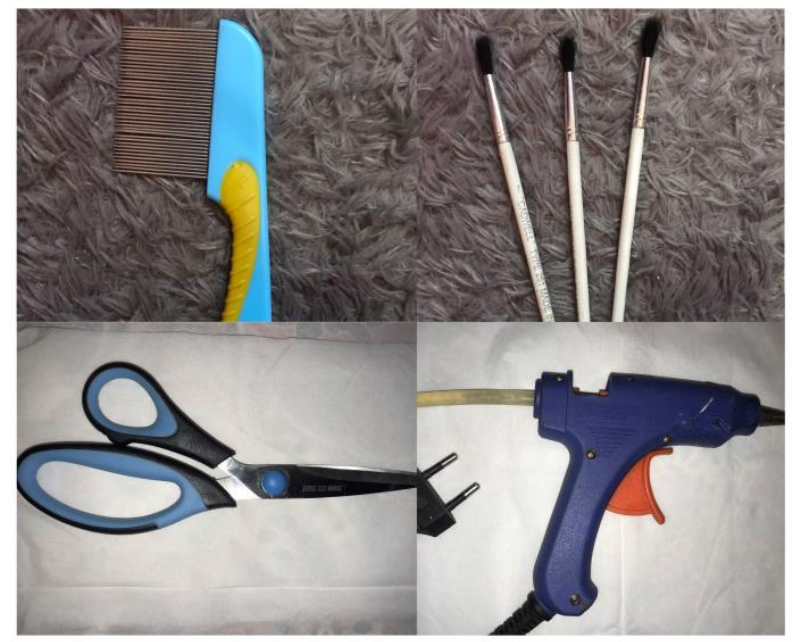

Gambar 5. Alat-alat yang digunakan dalam pembuatan geo produk Makrame Oluhuta. 
b. Bahan

1. Benang katun: merupakan bahan utama pembuatan makrame pada umumnya. Benang katun akan dibentuk menggunakan teknik simpul yang disesuaikan dengan kreasi makrame yang ingin dibuat.

2. Fosil kerang: bahan inilah yang membedakan Makrame Oluhuta dengan kerajinan makrame lain yaitu menggunakan fosil kerang sebagai hiasannya. Fosil kerang ini dicari dan dikumpulkan di sekitaran lokasi pantai Oluhuta dan situs lautan terangkat oleh tim PHP2D UKM Literasi bersama Gerakan Pemuda Pembaharu Desa Oluhuta.

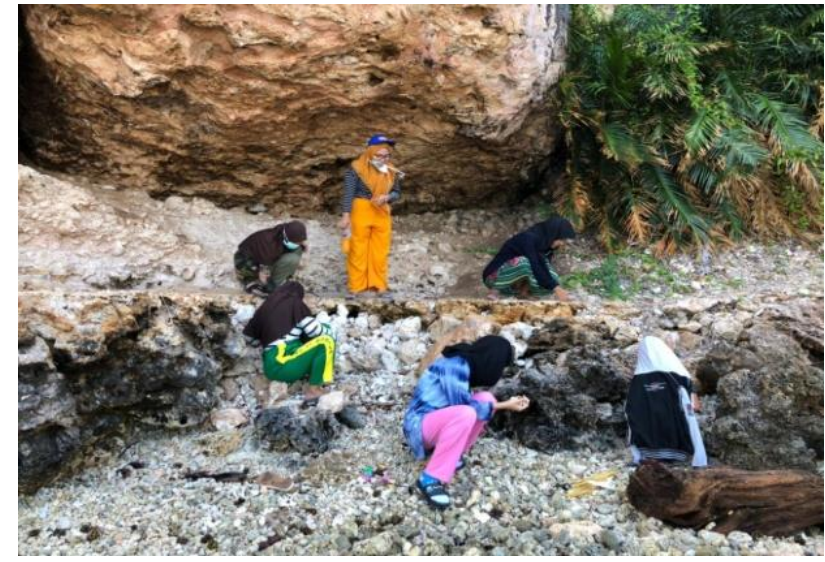

Gambar 6. Proses mencari fosil kerang di sekitar lokasi pantai Oluhuta dan situs lautan terangkat oleh tim PHP2D UKM Literasi bersama Gerakan Pemuda Pembaharu Desa Oluhuta.

3. Kayu dowel: berfungsi sebagai tempat untuk mengikat dan menggabungkan kerajinan makrame agar nantinya bisa digantungkan atau dipajang di dinding rumah atau keperluan dekorasi ruangan lainnya. Kayu dowel juga dapat digantikan dengan ranting-ranting pohon atau kayu sejenisnya.

4. Ring rotan: bahan ini juga memiliki fungsi yang sama dengan kayu dowel yaitu sebagai tempat untuk mengikat dan menggabungkan beberapa unit makrame yang dibuat, perbedaannya hanya pada bentuk saja. Jika kayu dowel bulat memanjang seperti tongkat, sedangkan ring rotan berbentuk lingkaran. Ini bisa dipilih sesuai selera yang diinginkan.

5. Lem tembak: digunakan untuk merekatkan fosil kerang pada benang katun yang sudah dibentuk.

6. Lem benang: berfungsi untuk merekatkan benang-benang yang sudah dililit, disimpul, maupun diikat agar lebih erat dan tidak mengalami pergeseran.

7. Cat lukis: digunakan untuk mewarnai fosil-fosil kerang agar lebih menarik dan estetik.

8. Semprotan rambut/Hair spray: berfungsi untuk membuat benang tetap pada posisinya agar tidak saling melilit setelah disisir. 


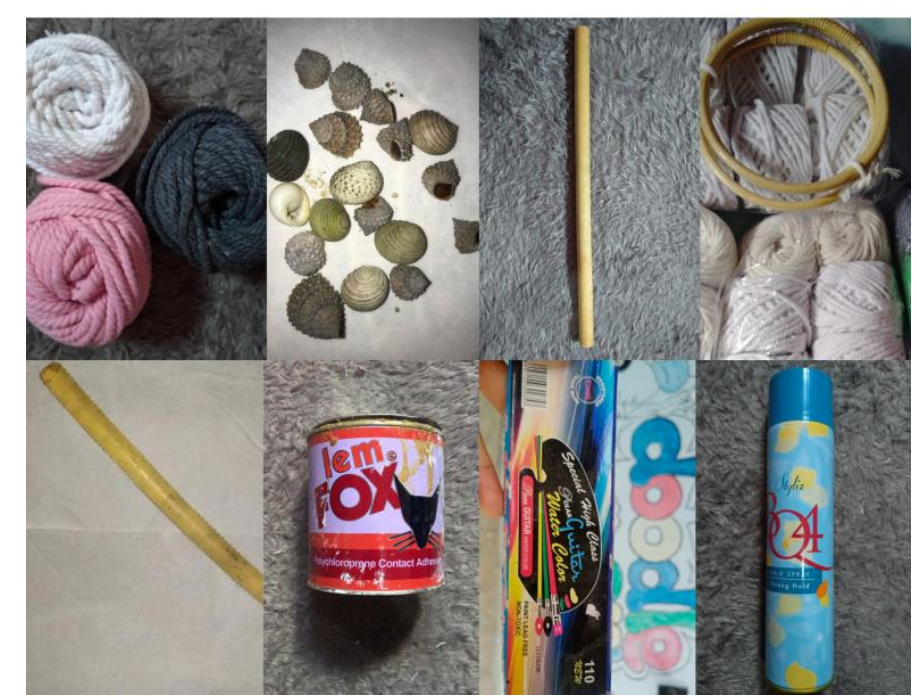

Gambar 7. Bahan-bahan yang digunakan dalam pembuatan geo produk Makrame Oluhuta.

4) Tahap Pelatihan

Setelah alat dan bahan sudah lengkap dan tersedia, tim PHP2D UKM Literasi melaksanakan pelatihan pembuatan geo produk Makrame Oluhuta pada masyarakat Desa Oluhuta yang dalam hal ini diwakili oleh Gerakan Pemuda Pembaharu (GPP) Desa Oluhuta. Pelatihan pembuatan Makrame Oluhuta ini dilakukan di salah satu rumah warga dengan pertimbangan agar jaraknya lebih dekat dengan tempat tinggal para anggota GPP yang akan mengikuti pelatihan tersebut. Adapun anggota GPP yang mengikuti pelatihan pembuatan geo produk Makrame Oluhuta berjumlah 7 orang.

Dalam pelatihan ini, bentuk makrame yang diajarkan hanyalah bentuk dedaunan. Dikarenakan bentuk ini dinilai mudah dibuat karena hanya menggunakan tiga simpul saja, yaitu simpul kepala, simpul tunggal, dan simpul mati, sehingga satu kali pelatihan saja diperkirakan sudah bisa mencapai hasil yang maksimal.

Pada tahap pelatihan, awalnya tim PHP2D UKM Literasi diwakili oleh satu orang selaku instruktor yang mengajarkan terlebih dahulu simpul-simpul yang digunakan. Setelah itu, instruktor memberikan arahan tentang tahapan-tahapan yang harus dilalui, mulai dari awal hingga akhir proses pembuatan Makrame Oluhuta. Selama proses pelatihan pembuatan geo produk Makrame Oluhuta, para anggota GPP terlihat sangat tanggap sehingga pelatihan yang dilaksanakan tidak memakan waktu yang banyak dan seluruh peserta pelatihan sudah mampu membuat serta mengkreasikan Makrame Oluhuta dengan sangat baik. 


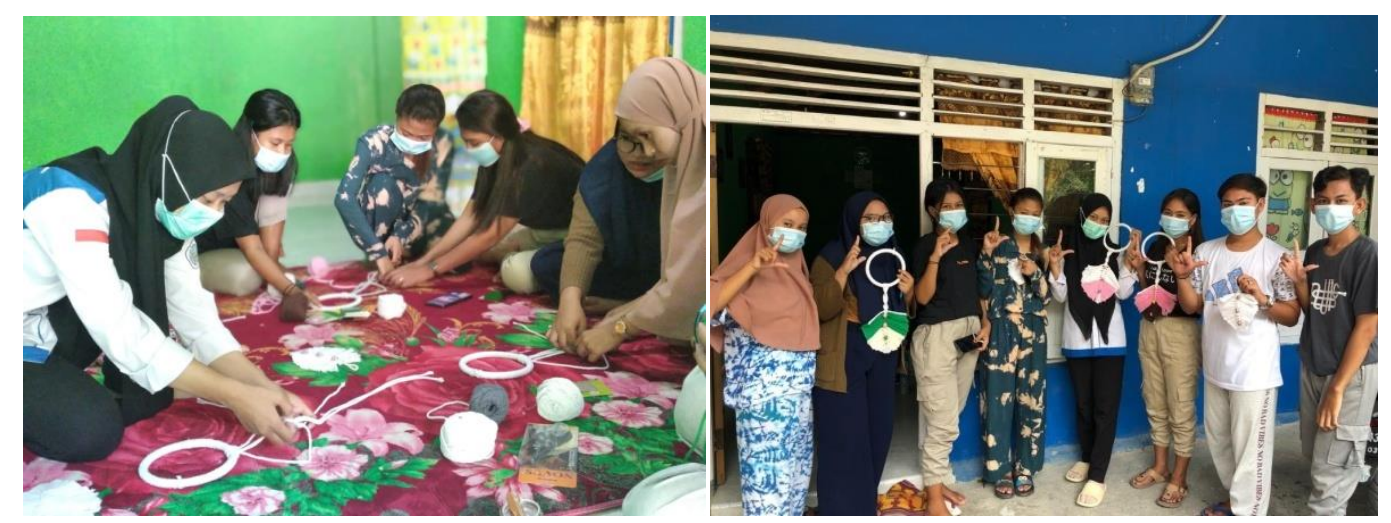

Gambar 8. Pelatihan pembuatan geo produk Makrame Oluhuta bersama Gerakan Pemuda Pembaharu Desa Oluhuta.

\section{5) Tahap Promosi}

Pada tahap ini, tim PHP2D UKM Literasi melakukan pengarahan dan pendampingan kepada Gerakan Pemuda Pembaharu Desa Oluhuta yang sudah melakukan pelatihan dalam mempromosikan geo produk Makrame Oluhuta melalui media sosial, di antaranya Facebook, Youtube, Instagram, dan TikTok. Sehingga tidak hanya diajarkan cara pembuatannya, namun juga dilakukan pembimbingan mengenai bagaimana mempromosikan geo produk Makrame Oluhuta yang dibalut dalam konten dan desain yang cantik, agar dapat menarik perhatian orang untuk membelinya. Adapun harga jual dari Makrame Oluhuta ini disesuaikan dengan jumlah dan ukurannya, sehingga semakin banyak dan semakin besar ukuran makrame maka harganya juga akan semakin tinggi. Kisaran harga dari geo produk ini yakni berkisar antara 20-50 ribu rupiah saja.

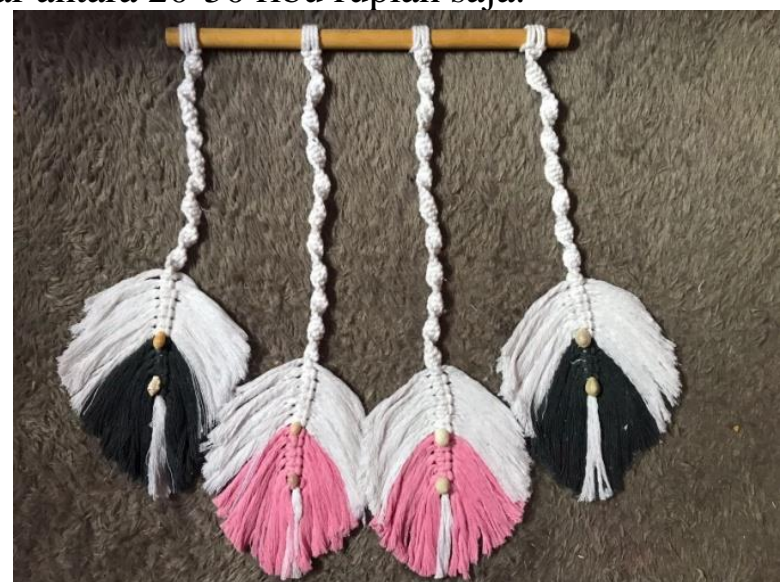

Gambar 9. Geo produk Makrame Oluhuta yang siap dipromosikan di media sosial.

\section{KESIMPULAN}

Dilihat dari keseluruhan kegiatan program pembuatan geo produk Makrame Oluhuta di Desa Oluhuta, dapat disimpulkan bahwa program ini berjalan dengan begitu baik akibat kerja sama yang terjalin antara tim PHP2D UKM Literasi dan mitra utamanya yaitu Gerakan Pemuda Pembaharu Desa Oluhuta. Dukungan dan antusiasme masyarakat terhadap program ini cukup tinggi apabila dilihat dari lima tahap yang telah dijelaskan di atas. Mulai dari tahap perencanaan, sosialisasi, pengadaan alat dan bahan, pelatihan pembuatan geo produk, sampai 
pada tahap promosi geo produk Makrame Oluhuta. Namun, di balik kelancaran program tersebut tentu saja terdapat beberapa kendala atau hambatan yang sempat terjadi, seperti ketersediaan bahan yang masih minim di toko-toko terdekat sehingga mengharuskan untuk memesannya secara online dan membutuhkan waktu yang lebih lama, juga keterbatasan waktu dan anggaran sehingga pelatihan hanya dapat dilakukan satu kali.

Akan tetapi, meski dengan segala hambatan dan kendala yang dialami, pembuatan geo produk Makrame Oluhuta tetap dapat berjalan dengan maksimal dan sesuai target. Selain itu dengan diadakannya pelatihan pembuatan geo produk juga menjadi media untuk menyalurkan sedikit ilmu dan pengetahuan yang akan berguna untuk pengembangan desa Oluhuta khususnya di sektor pariwisata dan juga ekonomi.

\section{DAFTAR PUSTAKA}

Manyoe, I. N., Arifin, Y. I., Napu, S. S. S., \& Suma, M. D. (2021, July). Assessment of the values of science, education, tourism and the risk degradation of Pentadio geothermal areas to developing geotourism in the Limboto Lake Plain, Gorontalo. In Journal of Physics: Conference Series (Vol. 1968, No. 1, p. 012047). IOP Publishing.

Patzak, M., \& Eder, W. (1998). " UNESCO GEOPARK". A new programme-a new UNESCO label. Geologica Balcanica, 28, 33-36.

Setyadi, D. A. (2012). Studi Komparasi Pengelolaan Geopark di Dunia untuk Pengembangan Pengelolaan Kawasan Cagar Alam Geologi Karangsambung. Jurnal Pembangunan Wilayah dan Kota, 8(4), 392-402.

Utami, A. R. (2016). Kompetensi Khas di Sektor Pariwisata. Esensi: Jurnal Bisnis dan Manajemen, 6(1), 75-88. 